\title{
Boy Toys and Liquid Joys: \\ Pleasure and Power in the Bower of Bliss
}

\author{
JOSEPH CAMPANA \\ Rice University
}

Early in Edmund Spenser's The Faerie Queene (1590), the Redcrosse Knight, just having departed the House of Pride, rests by a fountain "Disarmed all of yron-coted Plate" (1.7.2). ${ }^{1}$ The duplicitous Duessa will soon discover him in this vulnerable state, as will the giant Orgoglio, who defeats Redcrosse largely as a result of his separation from Una. Although his companion dwarf has warned him away from the House of Pride, with its parading vices and rotting foundations, Redcrosse's moral and psychic states justify his defeat at the hands of the giant, who finds him "Pourd out in loosnesse on the grassy grownd" (1.7.7). Spenser, however, takes extra time to explain Redcrosse's lassitude. The fountain from which he drinks bubbles up from a mythic substrate. In these waters dwells a nymph suffering from Phoebe's curse who, having wearied during a hunt and rested, was fixed to the spot: "her waters wexed dull and slow / And all that drinke thereof, do faint and feeble grow" (1.7.5). After Redcrosse drinks, his "chearefull bloud in fayntnes chill did melt" (1.7.6).

It would be easy to read this upwelling mythographic moment as a concretization and a condemnation of Redcrosse's moral situation. However, the fountain remains, as either a narrative or allegorical detail, superfluous. Superfluity is precisely its point, inasmuch as these episodes are concerned with the excess and scarcity of flows of pleasure and energy. That is, the fountain adumbrates a larger network of watery signifiers at the heart of the Legend of Temperance. Before Redcrosse drinks of the fountain, he sits by its waters, and

Hee feedes vpon the cooling shade, and bayes

His sweatie forehead in the breathing wynd,

1. All text citations (to book, canto, and stanza) are to Edmund Spenser, The Faerie Queene, 2nd ed., ed. A. C. Hamilton (London: Longman, 2007).

(c) 2009 by The University of Chicago. All rights reserved. 0026-8232/2009/10603-0004 $\$ 10.00$ 
Which through the trembling leaues full gently playes

Wherein the chearefull birds of sundry kynd

Doe chaunt sweet musick, to delight his mynd

The site of the fountain becomes a locus ameonus prefiguring the Bower of Bliss, the destruction of which is the apparent moral telos of book 2. Redcrosse at the fountain becomes the site of an exchange of fluids at once erotic and poetic. At the moment of his greatest moral lapse, his greatest susceptibility to dangerous pleasures, Redcrosse is also most receptive to aesthetic experience. As wind passes through the branches of trees and the throats of birds making song, water passes through Redcrosse's body, rendering it a part of an aesthetically responsive environment. His experience of liquidity requires him to set aside the signifiers of heroic masculinity that confirm the labor of his quest and convert the energies of his body to violent force. As Redcrosse disarms and experiences this morally questionable liquidity, he experiences his body as sensuous and sensible flesh.

This essay examines the pleasurable liquidity that confounds Redcrosse in the Legend of Holiness and that appears with increasing prominence in the Legend of Temperance, the part of The Faerie Queene most explicitly concerned with the validity of aesthetic and sexual enjoyment and one that features extraordinary figures of excessive pleasure. While James Carscallen has pointed out the way in which "water tempering wine" constitutes one of a number of emblems of appropriate temperance, we more often encounter characters who embody the sensual and censurable qualities of water: the uxorious Cymochles, whose heroism is diminished by his lust; the loose Phaedria, who ferries knights among the wandering isles; and the enchantress Acrasia, who seduces men and appears quite vividly in the poem soaked in the sweat of her sordid play. "Wanton toys" and "lascivious boys" lurk behind almost every bush against a backdrop of "liquid joys" and a host of tempting nymphs and sirens. Given Guyon's quest, the defeat of the irrationally intemperate Acrasia, it is easy to dismiss these liquid figures as obvious villains in the reductive moral landscape of allegorical romance. Yet the Legend of Temperance lingers over a series of disarmed, pleasured male bodies, forcing the reader to ask why Spenser explores masculine pleasure so expansively in a work of apparently unwavering moral purpose. Moreover, what governs the relationship between the pleasures of poetry (and the pleasured male

2. James Carscallen, "The Goodly Frame of Temperance: The Metaphor of Cosmos in The Faerie Queene, Book II," University of Toronto Quarterly 37 (1968): 136. 
body) and the imperatives of moral, heroic poetry? Such questions lead us inevitably to the legend's infamous conclusion, the destruction of the Bower of Bliss, which serves as a controversial touchstone for critics interested in understanding the relationship between aesthetic pleasure and the exercise of power in The Faerie Queene.

Although Guyon never experiences Redcrosse's vulnerability to pleasure at the fountain, such capacity for corporeal experience is critical for Spenser's understanding of Temperance. Indeed, for all that such vulnerability contradicts the moral rectitude of Guyon, the titular knight of Temperance who destroys the Bower of Bliss, it is openness to the transformative powers of pleasure that Spenser emphasizes in his account of Temperance. Joshua Scodel distills the representative critical view of the Bower of Bliss when he argues that "Spenser depicts laborious struggle against one's fallen nature and the temptations to which it is prone as a necessary part of virtue." Indeed, such Spenserian "temperance demands laborious action inimical to pleasurable idleness and the erotic excess with which it was so often associated." ${ }^{3}$ By struggling heroically against all pleasure as incontinent excess, Guyon and the Palmer become, in Scodel's view, representatives of Spenser's "eclectic synthesis of classical and Christian elements," one that elides Aristotle's distinction between continence (experiencing but resisting extreme pleasure or pleasure in the wrong things), and temperance (not experiencing extreme pleasure or pleasure in the wrong things, which is contrary to reason). Yet once we disentangle Spenser's poetic perspective from those of the wrathful Guyon and the moralistic Palmer, we can see that the concern of the Legend of Temperance is neither the heroic struggle against pleasure nor the reasonable moderation of pleasure. Spenser's true interest in temperance is in championing the capacity to be vulnerable to experience, a capacity under siege during the period due to the perception that such vulnerability connoted an immoral and effeminate failure to assume the mantle of proper masculinity. We witness, then, in the Legend of Temperance a thorough critique of an ideology of temperance embodied by Guyon and the Palmer, who exemplify the moderation of affect and the expropriation of energy by which heroic subjects are alienated from their own bodies and dedicated, quite violently, to the cause of virtue.

Such a critique enables Spenser to ask how the energies and impulses of the body might appear in the abeyance of the shaping force of martial violence, which secures the stability of a civilized order

3. Joshua Scodel, Excess and Mean in Early Modern Literature (Princeton University Press, 2002), 84. 
represented by heroic masculinity. Pleasure not only counteracts the masculine martial violence undergirding notions of virtue in Spenser's age but also enables the construction of truly aesthetic landscapes populated by bodies connected to one another in a state of shared vulnerability to sensation. By creating and destroying the Bower of Bliss, Spenser intervenes in a history of poetics that has tended to denigrate, moderate, excuse, or exclude pleasure. No mere advocate of moderation as a way of justifying the ethically compromised satisfactions of heroic violence, Spenser imagines a world in which our assumptions about the uses and ethics of pleasure must be imagined anew.

Although the language of delight and delectation saturates the history of poetry, responses to literary pleasures are characterized by ambivalence. For all the seductive allure of enjoyment, literary pleasure has been primarily defined by moral dispositions that not only censure but also obscure the very experience of pleasure. For Aristotle, "moral excellence," often the articulated goal of classical and (later) of early modern works of literature and rhetoric, was intimately tied to "pleasures and pains." Indeed, "it is on account of the pleasure that we do bad things, and on account of the pain that we abstain from noble ones." Consequently, Aristotle argues, "we ought to have been brought up in a particular way from our very youth, as Plato says, so as both to delight in and be pained by the things that we ought; this is the right education." Moreover, "the man who abstains from bodily pleasures and delights in this very fact is temperate, while the man who is annoyed at it is self-indulgent, and he who stands ground against things that are terrible and delights in this or at least is not pained is brave, while the one who is pained is a coward." ${ }^{4}$ True virtue, acquired through education and maintained through action, requires that pain and pleasure be experienced counterintuitively (pain as pleasure and pleasure as pain) or in some circumstances not at all.

Given the heuristic function associated with moderate pleasure and virtuous pain, it is no surprise to see literary pleasures consistently and dangerously associated with the sensual pleasures of corporeal experience. The fear was that poetry might incite improper desires and affects capable of altering habits of body or mind. Plato warns of the contagious power that imitation holds over young men, who should avoid poetic representations of "things unbecoming the free man ... nor yet any other shameful thing, lest from the imitation they imbibe the reality. Or have you not observed that imitations, if continued from 
youth far into life, settle down into habits and (second) nature in the body, the speech, and the thought?" ${ }^{5}$ Like an irresistible infusion, poetry might insinuate itself disastrously, working in ways "unbecoming" to the young boy who would be a "free man." Liquidity provides Plato with a figure of the overwhelming affective energies that corporeal and literary pains and pleasures share: "And so in regards to the emotions of sex and anger, and all the appetites and pains and pleasures of the soul which we say accompany all our actions, the effect of the poetic imitation is the same. For it waters and fosters these feelings when what we ought to do is dry them up." ${ }^{6}$ Poetry was not just a means of representing the problems of immoderate desire; rather, poetry and sexuality were partners in crime, and their common pleasures threatened the constitution of masculine agency. The solution to this problem was either the restriction of poetry to hymns in praise of the gods and poems in praise of morally salubrious heroic action or the exile of poetry, which Plato finally and famously recommends later in The Republic. Horace's Ars poetica would later influentially yoke pleasure and virtue, profit and delight, in a way that allowed later writers to cast pleasure as an enticement to virtue, the sweet coating of the bitter pill of moral truth.

The peculiar and discomfiting coexistence of literary, sensory, and often sexual pleasure bequeathed to early modernity a particular conundrum. What was most appealing about literature was, not surprisingly, potentially most ruinous, especially for young readers. Stephen Gosson's 1579 Schoole of Abuse, which inspired Philip Sidney's heroic Defence of Poetry (1595), casts the dangerous lure of poetry in the language of a pleasurable liquidity that in fact poisons the young, damaging the integrity of the masculine body. Whereas Gosson imagines himself as the true physician prepared to excise the rank flesh that is poetry, the poet is "the deceitfull Phisition" who "giueth sweete Syrropes to make his poison goe downe the smoother." The poet's song is like the "Syrens song [that] is the saylers wrack." Continuing the alimentary metaphor, Gosson compares "Poetes to Cookes [for] the pleasures of the one winnes the body from labor and conquereth the sense; the allurement of the other drawes the mind from virtue, and confoundeth wit." 7 Sidney's defense against Gosson debunks but reiterates the notion that poetry is "the nurse of abuse, infecting us with many pestilent desires, with a siren's sweetness

5. Plato, The Republic, trans. Paul Shorey (Cambridge, MA: Harvard University Press, 1935), 395c-d.

6. Ibid., $606 \mathrm{~d}$.

7. Stephen Gosson, The Schoole of Abuse (London, 1587), A4r. 
drawing the mind to the serpent's tail of sinful fancies." Moreover, Sidney defends (and thus inadvertently reinforces) the notion that the pleasures of poetry wreak havoc on the project of an assertive nationalist masculinity: "In other nations and in ours, before poets did soften us, we were full of courage, given to martial exercises, the pillars of manlike liberty, and not lulled asleep in shady idleness with poets' pastimes." ${ }^{8}$ As Walter J. Ong has argued, "The Renaissance humanist could be disturbed by the plausibility of the charge that literature, and poetry in particular, was actually soft or effeminate, so that, being purveyed to youngsters at the very age they should be maturing in manliness . . . it actually only weakens them." ${ }^{9}$ Indeed, Roger Ascham condemned romance for just this, worrying, "What toyes, that dayly readyng of such a booke ... may worke in the will of a yong jentelman?" 10

The very properties of poetry (its depictions, its sounds, and, more precisely, its rhymes) were sensuous, infectious, erotic, and potentially compromising. Ascham's fear of the effects of literary "toyes" (such as Arthurian romances) coincides with the use of the word "toy" to suggest, as Patricia Parker argues, that early modern men had reason to be concerned about "the potential impotence or irrelevance of the poetic vocation." ${ }^{11}$ Like all works of the imagination in early modernity, poetry might be worse than merely a misleading imitation (a "nurse of lies, a pleaser of fools," in John Harington's paraphrase of Cornelius Agrippa) in being also "a breeder of dangerous errors, and an enticer to wantonness." ${ }^{12}$ Poetry and pleasure alike are emptied of content, reduced to "vaine toyes," as they were often called; ${ }^{13}$ for, in order to defend against the pleasurable liquidity of aesthetic experience, which threatens to turn men into vulnerable boys, early modern commenta-

8. Philip Sidney, A Defence of Poetry, ed. Jan Van Dorsten (Oxford University Press, 1966), 51.

9. Walter J. Ong, Rhetoric, Romance, and Technology: Studies in the Interaction of Expression and Culture (Ithaca, NY: Cornell University Press, 1971), 130.

10. Roger Ascham, English Works: Toxophilus, Report of the Affaires and State of Germany, The Scholemaster, ed. William Aldis Wright (Cambridge University Press, 1904), 231.

11. Patricia Parker, Literary Fat Ladies: Rhetoric, Gender, and Property (London: Methuen, 1987), 56. See also W. W. Barker, "Rhetorical Romance: The 'Frivolous Toys' of Robert Greene," in Unfolded Tales: Essays on Renaissance Romance, ed. George M. Logan and Gordon Teskey (Ithaca, NY: Cornell University Press, 1989), 79-97.

12. John Harington, Orlando Furioso in English Heroical Verse (London, 1591), 4v.

13. "Vaine toyes" was a signature phrase appearing in a variety of early modern authors, including William Painter's Palace of Pleasure (1567), John Lyly's Euphues (1578), Philip Stubbes's The Anatomie of Abuses (1583), Robert Greene's Morando (1584), and Spenser's The Faerie Queene. 
tors defensively construed literature as a harmless toy. Rhyme was paradigmatic in this regard. For George Puttenham, rhyme ("proportion in concord" or "symphonie") consisted of "the eare taking pleasure to heare the like tune reported and to feele his returne," which "breedeth to th'eare a great compassion." 14 Thomas Campion, to the consternation of Samuel Daniel, despised what he perceived as the frivolous and facile nature of rhyme ("childish titillation" he called it), while George Gascoigne, no mere opponent of rhyme, warned his readers "to beware rhyme without reason." William Webbe, too, recommended "good and sensible rhyme" as opposed to poems in which words were "wrested contrary to natural inclination" or "disordered for the rhyme's sake," thus hindering the sense. Campion warned, more sternly, of the capacity of rhyme to force "a man ... to abjure his matter, and extend a conceit beyond all bounds of art." ${ }^{15}$ Rhyme could be dismissed as "childish titillation" precisely because it provoked in men responses contrary to reason and virtue, causing them to stray from appropriate subjects, extend beyond the bounds of proper composition, and rupture the integrity of the masculine writing subject.

The term "boy toy," or "toy-boy"-referring to "a young and attractive man regarded as the plaything of an older, often wealthier woman (or occas. man)"-would not enter into usage until the early 1980 s. $^{16}$ But while "boy toy" holds no currency as a phrase in early modernity, "boy" and "toy" (often along with words like "coy" and "joy") do associate significantly, forming a thematic, rhyming pair, especially in the landscapes of romance. Of course, boys were not merely potential victims of literary pleasure; they were also its emblem. If the boy actor, with his suggestion of gender transitivity and his participation in networks of homoerotic appeal and homosocial power, was central to the erotic politics of the early modern stage, the boy, as a potential subject or object of literary pleasure, was central to an understanding of early modern poetics. Catherine Belsey argues that "for more than a century" in early modernity, "boys were involved, implicated somehow, incorporated into female seductiveness" and that "boys, and the

14. George Puttenham, The Arte of English Poesie: Contriued into Three Books: the First of Poets and Poesie, the Second of Proportion, the Third of Ornament (1589; repr., Kent State University Press, 1970), 90, 91.

15. Sidney's "The Defence of Poesy" and Selected Renaissance Literary Criticism, ed. Gavin Alexander (New York: Penguin, 2004), 284, 239, 259, 284.

16. Oxford English Dictionary, 2nd ed., s.v. "boy toy." The phrase has come to be used more frequently to describe the young playthings of wealthier men, a development marked by Madonna's appropriation of the term, which appears on her belt buckle on the cover of her 1984 album Like a Virgin and was notable enough to earn her a mention in the $O E D$. 
pleasures they represent and enact, are included ... in the material of poetry at its most seductive." ${ }^{17}$

Like other Horatian apologists for poetry in early modernity, Sidney led the way in grounding poetry's validity in the masculinity and the forcefulness of its moral teachings and pleasure's validity in its ability to render attractive the sternest of virtues. Poetry may be "the first light-giver to ignorance, and first nurse whose milk by little and little enabled [readers] to feed afterwards of tougher knowledge." ${ }^{18}$ Poetry is designed to teach and delight, to draw the otherwise unwilling reader to tough and bitter knowledge by intermingling gall and honey. Indeed, poetry "giveth so sweet a prospect into the way, as will entice any man to enter into it." 19 Once again, the pleasure must be experienced in spite of itself: the expendable experience of sweetness enables the digestion of tough knowledge. Sidney's more or less representative view of literary pleasure leaves contemporary readers to ask: Does the articulation of the moral function of literature impoverish the language we have for discussing early modern aesthetic experience? What might the experience of pleasure, free of the confines of morality, tell us about the intersection of literary and corporeal enjoyment?

Rather than exiling pleasure or rendering it the mere handmaiden of morality, Spenser helps us inquire into what Michel Foucault influentially refers to as the uses of pleasure. Of classical culture Foucault remarks, "Foods, wines, and relations with women and boys constituted analogous ethical materials. ... They all raised the same question: how could one, how must one 'make use' (chrestai) of this dynamics of pleasures, desires, and acts?" ${ }^{20}$ Foucault examines the creation of "arts of living . . . and of 'using pleasure' according to austere and demanding principles" ${ }^{21}$ ruled by a struggle also familiar to the landscape of Edmund Spenser's Legend of Temperance, a struggle between enkrateia, or self-restraint, and akraisa, or incontinence. "Enkrateia," Foucault argues, "with its opposite, akrasia, is located on the axis of struggle, resistance, and combat; it is self-control, tension, 'continence'; enkrateia rules over pleasures and desires, but has to struggle to maintain control." ${ }^{22}$

17. Catherine Belsey, "Cleopatra's Seduction," in Alternative Shakespeares, vol. 2, ed. Terrence Hawkes (London: Routledge, 1996), 60.

18. Sidney, Defence of Poetry, 18.

19. Ibid., 40.

20. Michel Foucault, The Use of Pleasure, vol. 2 of The History of Sexuality, trans. Robert Hurley (New York: Random House, 1985), 51-52.

21. Ibid., 249.

22. Ibid., 65 . 
If for Foucault's Greeks the pleasures that could lead to akrasia were to be mastered and utilized, Spenser's Acrasia, the architect of the Bower of Bliss and the principle of perverse, feminine sexuality, appears at first to be the unambiguous target of the heroic force and moral ire of Guyon and his guide, the Palmer. ${ }^{23}$ Harry Berger describes Acrasia not only as "the enemy of Christian temperance" but also, more strikingly, as "an enemy of God, competing with the Divine creation." 24 Spenser was not, however, primarily interested in Acrasia's pleasurable bower as either an object of heroic conquest or a rival to divine creation and thus a problematic instance of the mimetic nature of poetry. He was interested in how pleasure might still be used, as Foucault argues, "to stylize a freedom." ${ }^{25}$ That is, Spenser deploys the manifold pleasures of the Bower of Bliss to release the masculine body from the constraining rhetoric of heroic, virtuous labor. The Legend of Temperance highlights flagrant displays of sensuous liquidity that transform heroic knights into boys or toys. Yet the effeminacy and immorality associated with excess pleasure render masculine subjects susceptible to corporeal experience, for Spenser evokes a poetics rooted in morally problematic flows of pleasure that could address early modern subjects' estrangement from their own bodies. Spenser was concerned with the excitable, vulnerable body, its transmissible energies, and the ethical states that might arise from an openness to pleasurable experience, which Alphonso Lingis describes when he defines libido as "the flux and reflux of tension and of susceptibility in the carnal substance." 26

As we examine the way pleasure renders the masculine heroic body vulnerable without destroying its integrity, we see in the Legend of Temperance, first, the emergence of an aesthetics and ethics of vulnerable corporeality and, second, the articulation of fantasies of autoerotic and homoerotic feminine sexualities that model orders of agency unavailable to early modern representations of heroic masculinity. Indeed, both male and female figures in the Legend of Temperance are best understood not as subjects prone to sexual acts, identities, or

23. On the classical and Christian distinctions between "continence" and "temperance" that may have influenced Spenser, see Harold Weatherby, Mirrors of Celestial Grace: Patristic Theology in Spenser's Allegory (University of Toronto Press, 1994).

24. Harry Berger, The Allegorical Temper: Vision and Reality in Book II of Spenser's "Faerie Queene" (New Haven, CT: Yale University Press, 1957), 67.

25. Foucault, Use of Pleasure, 97.

26. Alphonso Lingis, Libido: The French Existential Theories (Bloomington: Indiana University Press, 1984), vii. 
orientations; rather, all these figures exist as sites of pleasure possessing an orientation to corporeal energy, one most often expressed as mobility (or its lack). While the wholesale reconstruction of heroic masculinity would remain the task of the Legend of Chastity's exemplary figures, Britomart and Adonis, the Legend of Temperance provided Spenser the opportunity to examine pleasurable experience. Nowhere is Spenser's investigation of pleasurable experience more obvious than in figures of liquidity woven into the Spenserian stanza in a series of seemingly idle but thematically significant rhymes, including "boy," "toy," and "joy."

Readings of the Bower of Bliss have been categorized, as Paul Alpers argues, by "a felt disparity or conflict between moral purpose in The Faerie Queene and whatever most fills and pleases the imaginationbetween, as Grierson puts it, the Puritan and the Poet in Spenser." ${ }^{27}$ For W. B. Yeats, Spenser the poet emerges in spite of Spenser the puritan in the Legend of Temperance. "Spenser," Yeats argues, "except among those smooth pastoral scenes and lovely effeminate islands that have made him a great poet, tried to be of his time." ${ }^{28}$ The luscious landscapes of the bower make one wonder, as Arlene Okerlund suggests, whether "the sensuous beauty of the poetry is enough to make the reader, if not Guyon, forget about any quest after temperance." 29 C. S. Lewis was to resolve this tension between pleasure and morality by finding in Spenser's depictions of wanton bliss "a picture, one of the most powerful ever painted, of the whole sexual nature in disease." For Lewis, this diseased sexual nature appears in moments of intense voyeurism and in an array of pleasures that fail to attain either dignity or propriety. Lewis finds "not a kiss or an embrace in the whole island: only male prurience and female provocation." ${ }^{30}$ Lewis narrows considerably the range of sexuality and the power of pleasure, which are at worst prurience and provocation or at best a kiss and an embrace.

27. Paul Alpers, "Bower of Bliss," in The Spenser Encyclopedia, ed. A. C. Hamilton (University of Toronto Press, 1989), 105. Alpers argues that the Bower of Bliss, "peculiarly representative of Spenser's poetry," appears in what "is much the longest canto in The Faerie Queene ... and it has always been felt to have an importance commensurate with its length" (105).

28. W. B. Yeats, Essays and Introductions (New York: Macmillan, 1961), 370.

29. Arlene Okerlund, "Spenser's Wanton Maidens: Reader Psychology and the Bower of Bliss," PMLA 88 (1973): 62. Okerlund cites an anonymous letter to the February 27, 1930, Times Literary Supplement that argues, "Spenser's heart was not in his morality. When, as in this episode, it came to a struggle between his morality and his sense of beauty, his sense of beauty, very properly, triumphed."

30. C. S. Lewis, The Allegory of Love: A Study in Medieval Tradition (Oxford University Press, 1938), 332-33. 
While articles reprinted in A. C. Hamilton's Essential Articles for the Study of Edmund Spenser (1972) do take Lewis to task, they tend to address his view of the relationship between art and nature in the Bower of Bliss and the Garden of Adonis, mistaking Spenser's attempt to address the experience of pleasure in poetry for an attempt to address long-standing anxieties over the mimetic nature of poetry. N. S. Brooke does dissent from Lewis's view of sexuality, inasmuch as he argues that "the imagery of the bower is concerned not with a perversion of sex, but with a perversion of order." ${ }^{31}$ But in shifting from the problem of sex to the problem of order, Brooke removes pleasure from the conversation entirely. As Roland Barthes remarks, "An entire minor mythology would have us believe ... this peculiar idea that pleasure is simple, which is why it is championed or disdained." ${ }^{2}$ The sense that we must either sanction or condemn the pleasures in the Bower of Bliss clearly detracts from our reading of Spenser.

Although critics have largely departed from the style and concerns of the age of Lewis, recent readings of The Faerie Queene have not necessarily challenged the predominantly moral reading of Spenser, leaving pleasure largely unexamined. Critics of early modern sexuality have, for the most part, eschewed pleasure for other interests. Jonathan Goldberg admits in Sodometries that, while inspired by the work of Foucault, he also "wanted to see how relations between men (or between women and men) in the period provide the sites upon which later sexual identities could batten." 33 Accounts of Spenser follow suit in detailing the vicissitudes of heterosexuality in Amoretti (1595), Epithalamion (1595), and The Faerie Queene $;{ }^{34}$ male pastoral

31. N. S. Brooke, "C. S. Lewis and Spenser: Nature, Art and the Bower of Bliss," in Essential Articles for the Study of Edmund Spenser, ed. A. C. Hamilton (Hamden, CT: Archon, 1972), 27.

32. Roland Barthes, The Pleasure of the Text, trans. Richard Miller (New York: Farrar, Straus \& Giroux, 1975), 22.

33. Jonathan Goldberg, "Spenser's Familiar Letters," in Sodometries: Renaissance Texts, Modern Sexualities (Stanford University Press, 1992), 22.

34. William Keach's study of early modern Ovidian erotic narratives concludes by arguing for the ironic and expansive nature of the epyllion as a "challenge [to] Spenser's vision of the 'glorious fire' of love ideally realized in the creative chastity of marriage" (Elizabethan Erotic Verse [New Brunswick, NJ: Rutgers University Press, 1972], 232). Keach quite clearly articulates a commonly held position regarding The Faerie Queene, which is that Spenserian pleasure and sexuality participate almost exclusively in the formation or deformation of idealized heterosexual coupling. See, among others, particularly Thomas Roche, The Kindly Flame: A Study of the Third and Fourth Books of Spenser's "Faerie Queene" (Princeton University Press, 1964); and Lauren Silberman, Transforming Desire: Erotic Knowledge in Books Three and Four of "The Faerie Queene" (Berkeley: University of California Press, 1995). 
homoeroticism in The Shepheardes Calender (1579); ${ }^{35}$ male homosocial relations between lords and secretaries in Spenser's life $;^{36}$ and female homosexuality in The Faerie Queene. ${ }^{37}$

Such work seems to confirm David Halpern's assertion that scholars of the history of sexuality have repeated but not responded to Foucault's injunction to take seriously "bodies and pleasures." 38 As another commentator puts it, Foucault sought "the liberation of pleasures from the regime of sexuality and sexual identity." ${ }^{39}$ Foucault insists that "it is from the agency of sex that we have to free ourselves if ... we wish to assert against the hold of power bodies, pleasures, and knowledges in their multiplicity and their possibility of resistance. The basis for the counterattack . . . must be, not sex-desire, but bodies and pleasures." Foucault was interested in pleasure as that which might "escape the medical and naturalistic connotations inherent in the notion of desire." ${ }^{40}$ Valerie Traub's more recent The Renaissance of Lesbianism in Early Modern England takes up the subject of "the existence of a cultural awareness of women who desired other women in the early modern period" and "the complex and often contradictory modes of representation through which such desire was articulated." ${ }^{41}$ If the project seems, at first, to "batten" on later sexual identities (tracing a cultural transition in varieties of affective and physical female intimacy from harmless to objectionable), it takes up more complexly the way such intimacies render visible "the somatic and psychological components of erotic enjoyment." 42

35. See Goldberg, "Spenser's Familiar Letters"; Bruce R. Smith, "The Passionate Shepherd," in his Homosexual Desire in Shakespeare's England: A Cultural Poetics (University of Chicago Press, 1991), 79-115.

36. Richard Rambuss, Spenser's Secret Career (Cambridge University Press, 1993), 5661, and "Spenser's Life and Career," in The Cambridge Companion to Spenser, ed. Andrew Hadfield (Cambridge University Press, 2001), 13-16.

37. Only a scattering of articles exists on the presence of female homoerotic or - "lesbian" encounters in The Faerie Queene. See Camille Paglia, "The Apollonian Androgyne and The Faerie Queene," English Literary Renaissance 9 (1979): 42-63; Valerie Traub, The Renaissance of Lesbianism in Early Modern England (Cambridge University Press, 2002), 147-50; Kathryn Schwartz, "Dressed to Kill: Looking for Love in The Faerie Queene," in her Tough Love: Amazon Encounters in the English Renaissance (Durham, NC: Duke University Press, 2000), 137-74; Tracey Sedinger, "Women's Friendship and the Refusal of Lesbian Desire in The Faerie Queene," Criticism 42 (2000): 91-113.

38. See David M. Halpern, How to Do the History of Homosexuality (University of Chicago Press, 2002), 24-48. For a response to Halpern, see Carla Freccero, Queer/ Early/Modern (Durham, NC: Duke University Press, 2006), 31-50.

39. David Macey, The Lives of Michel Foucault (New York: Vintage, 1993), 358.

40. Michel Foucault, quoted ibid., 365.

41. Traub, Renaissance of Lesbianism, 6.

42. Ibid., 15. 
While scholars of the history of sexuality have not always attended to pleasure, other readers of Spenser effectively have exiled considerations of pleasure in affirming the proposition that more of the puri$\tan$ is to be found in The Faerie Queene than the poet. Anthony Esolen argues that Spenser's Legend of Temperance "advocates the energetic will and intolerance of the purest of all Old Testament kings," ${ }^{43}$ while Stephen Greenblatt locates in the bower an alignment of sexual and aesthetic pleasure with the forces that endanger cultural cohesion. "The Bower of Bliss," Greenblatt contends, must be destroyed not because its gratifications are unreal but because they threaten 'civility'civilization-which for Spenser is achieved only through renunciation and the constant exercise of power." 44

In both Greenblatt and his Freudian pretext, Civilization and Its Discontents (1930), pleasure is doubly coded as violent; pleasure violently assaults civilization and must be violently repulsed. As pleasure and sexuality are restricted to "the expression of an intense craving for release, which is overmastered only by a still more intense fear of release," aesthetic experience comes to be a function of cultural violence and therefore in collusion with political oppression: "Spenser's art does not lead us to perceive ideology critically, but rather affirms the ... inescapable moral power of ideology as that principle of truth toward which art forever yearns. It is art whose status is questioned in Spenser, not ideology." ${ }^{45}$ Many follow Greenblatt's lead, arguing that the Legend of Temperance is, as Richard McCabe says, located "in the common 'land' of colonial opportunity," where the trappings of romance bolster an ideological project. ${ }^{46}$ "By employing chivalric metaphors for the colonial enterprise," McCabe argues, "Spenser not only lends it the luster of heroic tradition but effectively elides its mercenary nature." ${ }^{47}$

43. Anthony Esolen, "Spenser's 'Alma Venus': Energy and Economics in the Bower of Bliss," English Literary Renaissance 23 (1993): 286.

44. Stephen Greenblatt, Renaissance Self-Fashioning: From More to Shakespeare (University of Chicago Press, 1980), 173. Greenblatt famously diagnoses in the Bower of Bliss a profound hostility to pleasure, which confirms the complicity of Spenserian poetics in the violence of early modern politics associated with Protestant iconoclasm, New World colonialism, and political oppression in Ireland.

45. Ibid., 173, 192. For critiques of Greenblatt, see David Lee Miller, "The Faerie Queene (1590)," in A Critical Companion to Spenser Studies, ed. Bart van Es (Houndsmill: Palgrave Macmillan, 2006), 139-65; and Richard McCabe, Spenser's Monstrous Regiment: Elizabethan Ireland and the Poetics of Difference (Oxford University Press, 2002).

46. McCabe, Spenser's Monstrous Regiment, 122. While McCabe takes up the relationship between Temperance and Ireland, others explore the relationship between Temperance and the New World. See David Read, Temperate Conquests: Spenser and the Spanish New World (Detroit: Wayne State University Press, 2000).

47. McCabe, Spenser's Monstrous Regiment, 126. 
Roland Greene has, more recently, expanded Greenblatt's frame of reference from self to world, claiming larger stakes for the destruction of the Bower of Bliss as "alterity" itself becomes "a danger to Christian temperance." ${ }^{48}$

An awareness of Spenser's relationship to Ireland or the New World need not result in a wholesale dismissal of the way art provides opportunities to investigate ideology. Such an interrogation of ideological violence requires that we ask whether or not the Legend of Temperance in fact advocates the violent application of moral temperance. Such readings, as Isobel Armstrong notes in recent conversations about the aesthetic, are typical of a particular "hermeneutics of suspicion." "Productive as this hermeneutics has been," she argues, "the concept of the aesthetic has been steadily emptied of content." Armstrong criticizes this failure "to address the democratic and radical potential of aesthetic discourse." ${ }^{49}$ Elsewhere, I have argued that we find evidence of Spenser's "radical aesthetic" in transformative patterns of pain in The Faerie Queene, ones that ask us to reconsider Spenser's purported commitment to the moral rectitude of heroic masculinity by noticing the corporeal workings of suffering and sympathy. ${ }^{50}$ Here I argue that we also find, in Spenser's Temperance, transformative patterns of pleasure that reshape the contours of heroic masculinity by suggesting the ethical ramifications of experiencing pleasure as a physical and affective vulnerability, an openness, to others.

In the Legend of Temperance, Spenser deploys Guyon and the Palmer to dramatize the disastrous consequences of the attempt to moderate pleasure and deploy bodily energy as violence in the service of heroic, moral agendas. Guyon's destructive acts represent what Foucault describes as one of two varieties of power-the sovereign power to destroy, which is characterized by the "right of seizure: of things, time, bodies, and ultimately life itself; it culminated in the privilege to seize hold of a life in order to suppress it." ${ }^{51}$ The Palmer represents the second variety of power, the force of fostering, or the moderating influence that disciplines and organizes the exemplar of temperance by, as Foucault put it, "distributing the living in the domain of value and utility" and treating "the body as a machine"

48. Roland Greene, "Spenser's Worldmaking: A Primer," in Worldmaking Spenser: Explorations in the Early Modern Age, ed. Patrick Cheney and Lauren Silberman (Lexington: University of Kentucky Press, 2000), 21.

49. Isobel Armstrong, The Radical Aesthetic (Oxford: Blackwell, 2000), 1-2.

50. See Joseph Campana, "On Not Defending Poetry: Spenser, Suffering, and the Energy of Affect," PMLA 120 (2005): 33-48.

51. Michel Foucault, An Introduction, vol. 1 of The History of Sexuality (New York: Random House, 1978), 136. 
and concentrating on "its disciplining, the optimalization of its capabilities, the extortion of its forces." ${ }^{52}$ Indeed, in the "Letter of the Authors," the Palmer first expropriates Guyon's labor at the court of Gloriana, where he "craued of the Faery Queene, to appoint him some knight to performe that aduenture," that is, the defeat of Acrasia, "which being assigned to Sir Guyon, he presently went forth with that same Palmer." 53 The Palmer becomes the externalization of the disciplinary techniques by which Guyon's energy is directed and his moral health maintained:

And with his steedy staffe did point his way:

His race with reason, and with words his will,

From fowle intemperaunce he ofte did stay,

And suffred not in wrath his hasty steps to stray.

This temperate discipline of the body that the Palmer achieves with reasonable words appears nowhere more plainly than in the House of Temperance. The opening stanza of the canto in which we encounter Alma's castle claims:

Of all Gods workes, which doe this world adorne,

There is no one more faire and excellent, Then is mans body both for powre and forme, Whiles it is kept in sober gouernment;

But none then it, more fowle and indecent, Distempred through misrule and passions bace:

It growes a Monster, and incontinent

Doth loose his dignitie and natiue grace.

Although a monstrous rabble of intemperate sensations assaults Alma's castle, the castle itself depicts the well-ordered body as a veritable factory of functions, one regulated to produce optimal operating efficiency and motivated by the discourse of moral health deriving from Alma herself, whose name means "nourishing." Michael Schoenfeldt points to Alma's castle as the key to the Legend of Temperance, which exposes stringent self-discipline as the foundation of the self. "Spenser," Schoenfeldt argues, "imagines the self as a fragile and unstable edifice, eternally under construction, and assailed on all sides (including the inside) by insurgent passions." By both repulsing the external assaults of the senses and monitoring and disciplining internal impulses,

52. Ibid., 144, 139.

53. Spenser, The Faerie Queene, 717. 
one achieves an identity "through the forceful imposition of rational order on energies that tend naturally to the twin poles of tyranny and anarchy." ${ }^{54}$ In essence, Spenser's critique of what Schoenfeldt explicates so lucidly in the Legend of Temperance-the mutually constitutive nature of inwardness and bodily continence-reveals how Alma and her castle realize the full disciplinary force of the Palmer's fostering influence. Indeed, when Alma brings the knight into the chamber of the heart, the seat of the passions, she stills the delightful hubbub. Before her entrance, the heart is witness to "diverse delights" (including singing, laughing, and gaming, or "toy"-ing) and moody affects (shame and grief, envy and coyness). But,

Soone as the gracious Alma came in place, They all attonce out of their seates arose, And to her homage made, with humble grace

At the end of the episode, while Guyon journeys on to destroy the Bower of Bliss, Arthur remains at Alma's castle, his labor expropriated for the safety of the keep, as he defeats the monstrous Maleger, who represents the incursion of dangerous, diseased sensations. Alma, Arthur, the Palmer, and Guyon may guarantee order, but at what price to the body? As Fredric Jameson argues, "To discipline [the body], to give it the proper tasks and ask it to repress its other random impulses, is at once to limit its effectiveness, or, even worse, to damage it irretrievably." ${ }^{55}$ Marx referred to this limitation as the phenomenon of estranged labor, whereby the worker is alienated not only from the products of his own labor but from the essential energy of his laboring body and mind: "It is activity as suffering, strength as weakness, begetting as emasculating, the worker's own physical and mental energy, his personal life-indeed, what is life but activity?-as an activity which is turned against him, independent of him and not belonging to him." Marx describes, then, the alienation of the worker from the product of his labor, from the energy of his own activity, and, most important, from "the sensuous external world." ${ }^{56}$ In the literature of epic and chivalric romance, heroic masculinity is that form of estranged labor by which the energies of the human body are deployed as virtue, and the signifiers of that masculinity reflect such estrangement.

54. Michael Schoenfeldt, Bodies and Selves in Early Modern England: Physiology and Inwardness in Spenser, Shakespeare, Herbert, and Milton (Cambridge University Press, 1999), 73.

55. Fredric Jameson, "Pleasure: A Political Issue," in Formations of Pleasure, ed. Tony Bennett et al. (London: Routledge, 1983), 9.

56. Karl Marx, Economic and Philosophical Manuscripts of 1844 (New York: International Publishers, 1964), 111. 
The Legend of Temperance certainly dramatizes the attempt to violently exile the distractions of pleasure in the name of moderation, but it also exposes the failure of Guyon and the Palmer to employ the estranged energies of masculinity in the service of virtuous labor. The very identification of Spenser's poetics with the perspective of Guyon and the Palmer is remarkable in light of the proem that functions as a preface to both the first book and the entire 1590 edition of The Faerie Queene. There, Spenser clearly repudiates heroic masculinity, heros, in his invocation of the aid of eros:

And thou most dreaded impe of highest Ioue,

Faire Venus sonne, that with thy cruell dart

At that good knight so cunningly didst roue,

That glorious fire it kindled in his hart,

Lay now thy deadly Heben bow apart,

And with thy mother mylde come to mine ayde:

Come both, and with you bring triumphant Mart,

In loues and gentle iollities arraid,

After his murdrous spoyles and bloudie rage allayd.

(1.proem.3)

Eros, or Cupid, is identified by virtue of his unnamed victim, Arthur, who has "suffered so much ill" in his futile quest for the love of Gloriana (1.proem.2). This futile, questing desire produces the very dialectic of sexuality and violence that Greenblatt identifies with The Faerie Queene, with Arthur, that exemplar of Magnificence, or all virtues, its perfect embodiment. ${ }^{57}$ In spite of the narrator's compassion for Arthur's plight, the proem replaces the desire of the erotic quest and conquest with the desire to disarm and set aside the violence of heroic poetry. Cupid must lay down his "deadly Heben bow" so that he might help his "mother mild" to summon a Mars whose "murdrous spoyles and bloudie rage" are "allayd." The disarmed Cupid, the mild Venus, and the pacified Mars provide a trinity that displaces Calliope (the epic Muse invoked previously in the proem), the questing Arthur, and the absent Gloriana, and this alters the logic of epic invocation.

This reconstituted erotic trinity forces us to modify our understanding of Spenser's oft-cited intention, "Fierce warres and faithfull loues shall moralize my song" (1.proem.1). If we are to consider The Faerie Queene a poem concerned with virtue, we must remember the root meaning of the word, turning our attention from morality to masculinity. Indeed, it is not art that Spenser's Bower of Bliss calls into question as a way of championing morality and obscuring ideology. Rather, it is that ethos of heroic masculinity that Spenser will consistently call 
into question, making its reconstitution the task of the 1590 edition of The Faerie Queene. As perverse pleasures distract masculine knights from their quests and combats, they unleash in the landscape of the Legend of Temperance a wholly new relationship to a gendered dynamics of corporeal energy.

As a commodity in the Legend of Temperance, energy is not only precious but gendered, being primarily the province of women and boys. By contrast, men regularly struggle to put themselves in motion, as emblematized by Guyon's loss of his horse early on in the legend (2.2.11). The vain, foolish Braggadochio, who unintentionally parodies the gentility and masculinity of romance heroism, steals Guyon's horse, which Guyon will not recover until late in the Legend of Justice. The horse suggests the restless passion, the erotic thrust of heroic masculinity, as when Guyon is introduced and identified with his energetic steed. ${ }^{58}$ Moderation comes from the Palmer, who "euer with slow pace the knight did lead, / Who taught his trampling steed with equall steps to tread" (2.1.7). Guyon's trampling steed, of course, also reprises Redcrosse's "angry steed," who "did chide his foming bitt / As much disdayning to the curbe to yield" (1.1.1). Guyon's loss of locomotion expresses a lack of masculine force. Instead of pricking on the plain, Guyon must walk, bearing the "double burden" (2.2.12) of wrecked masculinity as he carries the dead Mordant's armor "with bloud defilde, / An heauie load" (2.2.11). Mordant is, of course, the first boy toy we encounter in the Legend of Temperance, being the lover and victim of Acrasia. Even in death, Mordant, "the flower of his age," appears oddly vital; the passage lingers on his "ruddie lips," noting that "rosy red / Did paint his chearefull cheekes" (2.1.41). Even in death, it is clear that Mordant was "in his freshest flowre of lusty hed, I Fitt to inflame" (2.1.41). Mordant displays a pleasurable, seductive energy that distracts from both the pain of his grieving widow, Amavia, and the stern morality of Guyon and his Palmer. Guyon has lost the unthinking force of epic masculinity and must bear material remainders of their wrecked masculinity as he carries away Mordant's armor.

The Legend of Temperance does offer reason to wonder if masculinity is not vitalized by pleasure but rather stupefied. Mordant, after all, is dead, and his counterpart at the close of book 2, Verdant, sinks into the embrace of Acrasia. Yet these moments of stupefaction also

58. In a well-known analogy from Plato's Phaedrus, the soul is like a charioteer (reason) directing two horses, one white (passion) and one black (appetite). This tripartite soul appears as well in bk. 4 of Plato's Republic, which describes the three drivers immediately following a lengthy discussion of the virtue of temperance. 
witness a sexual vitality that emerges only as masculinity is disarmed. Verdant combines a "sweet" and boyish "regard" with "manly sternesse" but displays only the first signs of that manliness, for "on his tender lips the downy heare / Did now but freshly spring, and silken blossoms beare" (2.12.79). Verdant presents the portrait of the ideal youth, with that particular oscillation between masculine and feminine characteristics so energizing to early modern narrative. To be sure, the narrator pities and decries Verdant's bondage to the pleasures of Acrasia as displayed in his abandoned armaments:

His warlike Armes, the ydle instruments

Of sleeping praise, were hong vpon a tree,

And his braue shield, full of old moniments,

Was fowly ras't, that none the signes might see,

Ne for them, ne for honour cared hee,

Ne ought, that did to his aduancement tend,

But in lewd loues, and wastfull luxuree

His dayes, his goods, his bodie he did spend:

O horrible enchantment, that him so did blend.

Like Aeneas distracted by Dido or like Redcrosse poured out in looseness, Verdant's heroic attributes suffer neglect as he sinks into Acrasia's lap of luxury, a place of immoral but pleasurable expenditures of energy ("His dayes, his goods, his bodie he did spend"). The opening of the stanza displays the concatenation of heroic action and virtuous poetry at the moment of their failure, as the instruments of war, which Parker also construes as the instruments of writing, hanging idle on a tree. Indeed, Parker finds here an indication of the ambivalence and perhaps resistance of "lyric poets in the era of Spenser, subject to a queen who very much demanded their voices. Hanging up one's instrument stands here as a sign of resistance." ${ }^{59}$ In response to anxieties about the potential obsolescence of poetry and to subjection to the rule of a woman, Parker argues, poets fashioned means of mastering the powerful beloved through the Petrarchan lyric, which explains, too, the destruction of the Bower of Bliss. Parker states, "As with the dyadic antagonism of Petrarchan lyric, there seems to be here, ironically, no temperate middle way, no alternative to the polarity of subject or be subjected." 60

Critics have tended, with Parker, to identify the sexual blending we associate with Acrasia and Verdant as the reprehensible suspension of 
martial force, a lack of mobility that indicates enslavement to pleasure and idolatrous attachment to nature. Esolen argues that Alma and Acrasia represent nature in bono and in malo, respectively, the former nourishing and the latter enervating. ${ }^{61}$ Verdant is, of course, wrapped in Acrasia's embrace, surrounded by "Many faire Ladies and lasciuious boyes, / That euer mixt their song with light licentious toyes" (2.12.72):

And all that while, right ouer him she hong,

With her false eyes fast fixed in his sight,

As seeking medicine, whence she was stong,

Or greedily depasturing delight:

And oft inclining downe with kisses light,

For feare of waking him, his lips bedewd,

And through his humid eyes did sucke his spright,

Quite molten into lust and pleasure lewd;

Wherewith she sighed soft, as if his case she rewd.

Much has been made of the easily condemned Acrasia in her seemingly parasitic attachment to Verdant, as she draws "his spright" with her "false eyes" through his "humid eyes."

Yet we also note a wholesale reorienting of the power of the gaze in this scene when we compare Verdant and Acrasia to their prototypes, Rinaldo and Armida, in Tasso's Gerusalemme liberata (1581). There, the valiant Christian Rinaldo lies in the clutches of the Saracen sorceress Armida. Rinaldo sinks into the same liquid joy that consumes Verdant, but it is he who does the looking: "His hungry eyes upon her face he fed / And feeding them so pin'd himself away." ${ }^{62}$ Rinaldo's desire is as active as his gaze and yet reprehensibly effeminate. Although Verdant receives no direct approbation, he does display the disarmed masculinity that Spenser calls for in the proem to book 1 . And even though Acrasia might seem tantalizingly close to the evil Armida, she compares favorably with the aggressive Venus of Shakespeare's closely contemporary Venus and Adonis (1593). ${ }^{63}$ Despite being the embodiment of evil intemperance, Acrasia retains very human qualities, such as her

61. "Spenser depicts the elevation of nature to deity as unnatural and idolatrous and the Lucretian Venus as ungenerative unless Christianized-that is, remasculinized and absorbed into the theological and social hierarchies implicit in Alma's castle" (Esolen, "Spenser's 'Alma Venus,'” 285).

62. Torquato Tasso, Jerusalem Delivered, trans. Edward Fairfax (New York: Capricorn, 1963), 16.19.1-2.

63. Early in Shakespeare's Venus and Adonis, Venus exercises physical mastery over Adonis, humiliating him in the process: "Being so enrag'd, desire doth lend her force / Courageously to pluck him from his horse" (29-30). All references are to The Riverside Shakespeare, ed. G. Blakemore Evans (New York: Houghton Mifflin, 1997). 
care for the youth-her "feare of waking him," her sighing "as if his case she rewd." Acrasia's display of compassion seems at odds with her apparent use of Verdant as a disposable source of pleasure and energy, but her compassion suggests that the disarming of heroic masculinity opens up the possibility of relationships grounded in mutuality. Just as Tasso cannot bring himself to damn the sorceress Armida (she converts to Christianity in order to marry Rinaldo), Spenser cannot bring himself wholly to damn Acrasia because she renders inflexibly "virtuous" masculinity receptive to experience and vulnerable to care.

Whereas the portrait of Verdant stresses an exchange of energy and compassion through a shared experience of liquid pleasure, Cymochles' effeminate postures enable his receptivity to aesthetic experience. Like Verdant,

now he has pourd out his ydle mynd

In daintie delices, and lauish ioyes,

Hauing his warlike weapons cast behynd,

And flowes in pleasures, and vaine pleasing toyes

Mingled emongst loose Ladies and lasciuious boyes.

Like other masculine "victims" of effeminizing pleasure (including Verdant whose arms are like instruments), Cymochles experiences, in this vulnerable state, a heightened awareness of aesthetic experience. In the architecture of the bower itself is evidence of "art stryuing to compayre / With nature," along with "daintie odours," "bounteous smels," and "painted colors" (2.5.29). Experience is here aesthetic in its root sense, which refers to sensory perception long before it comes to refer to the experience of works of art. Although masculine force naps by the fountain, the body wakes to a different order of sensation. The trickling waters of the bower are often host to "the wearie Traueiler." He quenches his thirst in the water,

And then by it his wearie limbes display, Whiles creeping slomber made him to forget His former payne, and wypt away his toilsom sweat.

This hypothetical traveler is no longer absorbed in toil, in the experience of a kind of pain that subjects the body to the imperatives of labor in the form of a quest. Instead, foregrounded here is a body at rest and in a position to produce, rather than expend, energy. In this grove, "mery birdes of euery sorte / Chaunted alowd their chearefull harmonee." The harmony of these sounds energizes the listener, 
making "a sweete consort, / That quickned the dull spright with musicall comfort" (2.5.31). The quickening of the sprite comes with the surrender of masculine force to an aesthetic or sensory relationship to the body, as signaled by a cascade of auditory, olfactory, and tactile signifiers in the description of the bower. Cymochles' gratuitous experience resonates with Jameson's defense of the pleasures of the body: "Lazy, shot through with fits of boredom or enthusiasm . . . listening for the fainter vibrations of a sensorium largely numbed by civilization and rationalization, sensitive to the messages of throbs too immediate, too recognizable as pain or pleasure-maybe all this is not to be described as self-indulgence after all." 64

The display of Cymochles' pleasured, unarmed body introduces him into the bower's complex circuits of voyeurism as both the subject and the object of an erotic gaze. Like the traveler's, Cymochles' body is laid out to view, "carelesly displaid, / In secrete shadow from the sunny ray" (2.5.32). As Cymochles luxuriates "amidst a flock of Damzelles" who entice, incite, and arouse him with "wanton follies and light meriment" (2.5.32), the women in turn display their bodies in a series of acrobatic games, which "loosely disaray" their "vpper parts of meet habiliments / And shewd them naked, deckt with many ornaments" (2.5.32). Valerie Traub, among others, comments on the "poetics of voyeurism" in Spenser, which fashions "scenes ostensibly in the service of a desiring male viewer." 65 Traub's account complicates masculine voyeurism by locating a female intimacy and homoeroticism in the display of breasts in the Bower of Bliss. The portrait of the recumbent Cymochles further complicates the prerogatives of masculine viewing:

He, like an Adder, lurking in the weedes,

His wandering thought in deep desire does steepe,

And his fraile eye with spoyle of beauty feedes;

Sometimes he falsely faines himself to sleepe,

Whiles through their lids his wanton eies do peepe,

To steale a snatch of amorous conceipt,

Whereby close fire into his heart does creepe:

So, he them deceiues, deceiud in his deceipt,

Made dronke with drugs of deare voluptuous receipt.

The dangerous power of masculine spectatorship, as indicated by the image of the adder, strays consistently from potency to distraction. The formerly valiant Cymochles possesses a "wandering thought" and a "fraile eye," and while he "feedes" upon their beauty, his spectator-

64. Jameson, "Pleasure," 9.

65. Traub, Renaissance of Lesbianism, 148. 
ship of the alluring women is far from dominant. Cymochles neither inflicts nor suffers the power of the gaze. ${ }^{66}$ Looking becomes, in this scene, a game of erotic mutuality in which all parties display and are displayed. Cymochles' purportedly superior position, as one who looks, is tempered not only by the display of his own body but also by the awareness of the feminine "objects" of perception. After all, Cymochles is "deceiud in his deceipt." The use of "deceipt" here certainly indicates moral censure, but Cymochles is, more importantly, "dronk with drugs of deare voluptuous receipt." The state of voluptuous receptivity indicates a relationship to desire in which "to perceive is to become perceptible," to "insert oneself . . . into the field one looks into." 67 Cymochles' surrender of epic force results in a receptivity that reprehensibly disrupts the morality aligned with masculinity's efficacious violence.

Cymochles' visible receptivity to pleasure also renders visible his fascination with the female body and its capacity for mobility as it performs, teases, and toys. Even the scandalous display of nudity derives from a series of ongoing motions, which might have appeared in figures of immobility such as in the static tableaux or disarticulated parts common to the early modern blazon. As Cymochles attends not merely to the nudity of static female bodies but to female bodies in motion, erotic fascination in the bower concerns displays of energy and locomotion. One of the most famous moments of voyeurism in The Faerie Queene, Guyon's encounter with two nymphs in a fountain, confirms this fascination with feminine mobility. Encountering yet another of the bower's liquid joys, Guyon notes “Two naked Damzelles,"

Which therein bathing, seemed to contend,

And wrestle wantonly, ne car'd to hyde,

Their dainty parts from vew of any, which them eyd.

Howard Hendrix argues that this is Guyon's only clear moment of temptation in book 2 and that critics have been "notably reticent and circumspect in discussing how and why this spectacle should possess such particular seductiveness," just as "the fact that the young women are wrestling is conspicuously absent from most discussions." ${ }^{68}$ Hendrix

66. On the power traditionally associated with masculine pleasure and spectatorship, see Nancy Vickers, "Diana Described: Scattered Woman and Scattered Rhyme," Critical Inquiry 8 (1981): 265-79; and the influential article by Laura Mulvey, "Visual Pleasure and Narrative Cinema," Screen 16 (1975): 6-18.

67. Lingis, Libido, 52.

68. Howard Hendrix, "'Those Wandring Eyes of His': Watching Guyon Watch the Naked Damsels Wrestling," Assays 7 (1992): 71. 
sees here the power of Guyon's male gaze to eroticize the scene in a way consonant with patriarchal structures of power, as a defense against feminine agency.

While Cymochles and Guyon certainly participate in a form of voyeurism attentive to exposed female bodies, the Legend of Temperance attends more closely to an erotic fascination appearance of autonomy constituted by the capacity for locomotion. Guyon is in constant danger of falling into stasis-as when he loses his horse, when he collapses outside the Cave of Mammon, or when he becomes captivated by the nymphs in the fountain. But of the wanton wrestling of the latter, we learn that

Sometimes the one would lift the other quight

Aboue the waters, and then downe againe

Her plong, as ouer maystered by might,

Where both awhile would couered remaine,

And each the other from to rise restraine

It is, of course, true that one consequence of the wrestling is the exposure of the nymphs' flesh as "th'amarous sweet spoiles to greedy eyes reuele" (2.12.64). Yet, as in Cymochles' encounter with the nymphs of the Bower of Bliss, the revelation of flesh is an aspect of a larger circuit of motion, one in which mastery shifts back and forth, never resting in solely one party. This very circuit of motion might remind us of Guyon's encounters with the fountain's ornamentation:

Most goodly it with curious ymageree

Was ouerwrought, and shapes of naked boyes,

Of which some seemd with liuely iollitee,

To fly about, playing their wanton toyes,

Whylest others did them selues embay in liquid ioyes

Even the static monument here depicted suggests, to Guyon, activity, in the flying, playing, and bathing of the boys in their "liuely iollitee." The aesthetic power of the fountain rests not in stasis but in the suggestion of motion; even the struggle between art and nature seems uncannily like the wrestling nymphs in that each suggests a pleasurable and playful physicality:

So striuing each th'other to vndermine,

Each did the others worke more beautify;

So diff'ring both in willes, agreed in fine:

So all agreed through sweete diuersity,

This Gardin to adorne with all variety. 
The erotic play of the nymphs is competitive but not conflictual; likewise, in the Bower of Bliss, "all pleasures plenteously abownd, / And none does others happinesse enuye" (2.12.58). Art and nature may also compete, "striuing each th'other to vndermine," but their differing "willes" coincide in the same end-"sweet diuersity." The boy toys who attend this fountain produce not only a spectacle of female seductiveness but a variety of aesthetic pleasure that helps us revise our understanding of the body's capacity to expend energy and to exert agency in the absence of heroic violence.

The nymphs that fascinate Guyon form a self-involved, erotic circuit of energy and resistance, motion and stasis. They are, for Guyon, not only an engine of motion but also, in their erotic play, signifiers of a sexuality manifest in the language of motion and distracting because apparently complete in itself. Guyon's arrested progress is remarkably like that of the Lover in the Romance of the Rose (ca. 1320), yet again delayed from consummation by a spectacle arranged by the figure Diversion:

In the middle of the carol, Diversion, with great nobility, directed the dancing of two darling young ladies dressed only in kirtles, with their hair in single braids. It is useless to speak of how quaintly they danced: each one came very prettily toward the other, and when they were close they thrust their mouths forward in such a way that it would have seemed to you that they were kissing each other on the face. They knew well how to move their bodies. I don't know how to describe it to you, but I never would have wanted to move as long as I could see these people bestirring themselves to carol and dance.

I stood there motionless, watching the carol. ${ }^{69}$

The precise, alluring motions of the two girls immobilize the Lover. The figure of Diversion is, himself, a boy toy, for, as we are told, "never among men will you come upon any place where you will see a more handsome man. ... He had neither beard nor mustache, except for a very little down, for he was a young man." ${ }^{70}$ The entire scene suggests that the pleasurable experience of distraction immobilizes the violent will to erotic closure. Guyon, too, stands motionless as he witnesses in the Bower of Bliss a distracted erotic, one that has slipped from the driving telos of sexual consummation and narrative conclusion. In these scenes we witness not just the interruption of masculine desire but the unleashing of a different order of sexuality, a feminine homoerotics rooted in a dialectic of competition and collusion, which

69. Guillaume de Lorris and Jean de Meun, The Romance of the Rose, trans. Charles Dahlberg (Princeton University Press, 1995), 41.

70. Ibid. 
provides the energy that motivates the mutual beautification of art and nature in the Bower of Bliss.

As Guyon himself becomes an object of display (not only noticed by the nymphs but noticeably aroused), the Palmer's moral imperatives interrupt the triangle, thus preventing Guyon from succumbing to erotic vulnerability. The Palmer may draw Guyon's eyes from spectacles of distraction, but the sound of pleasure inevitably surrounds them both:

Eftsoones they heard a most melodious sound,
Of all that mote delight a daintie eare,
Such as attonce might not on liuing ground,
Saue in this Paradise, be heard elsewhere:
Right hard it was, for wight, which did it heare,
To read, what manner musicke that mote bee:
For all that pleasing is to liuing eare,
Was there consorted in one harmonee,
Birdes, voices, instruments, windes, waters, all agree.

An erotically charged experience of mutual participation pervades the bower, bringing all sounds and all things into concord. In the course of the stanza, the "daintie eare," trained to experience delight, becomes a "liuing eare" as pleasure is attuned to a broader harmony. Like Redcrosse, Verdant, and Cymochles, Guyon witnesses a kind of sensory plenitude that his own body, by virtue of being a body, is capable of participating in or resonating with in "one harmonee."

We see, in the Legend of Temperance, a progression from a liberating masculine lassitude (that renders the heroic male body vulnerable to experience) to a fascination with erotic mobility. This fascination indicates an attempt to conceive of human agency and bodily energy without the violent constraints of heroic masculine assertion. Such mobility finds its most dynamic expression in the figure of Phaedria, who provides locomotion in the waterways of Acrasia's domain. She appears, for the first time, in

A little Gondelay, bedecked trim

With boughes and arbours wouen cunningly,

That like a little forest seemed outwardly.

Like the bower that mingles art and nature, Phaedria's boat suggests a cleverly constructed camouflage, yet it also suggests that in recreating the topos of romance, the "little forest," Phaedria has created her own self-contained world, one that moves around like one of the wander- 
ing islands around which she navigates. Phaedria exhibits an utterly self-sufficient relationship to pleasure and locomotion:

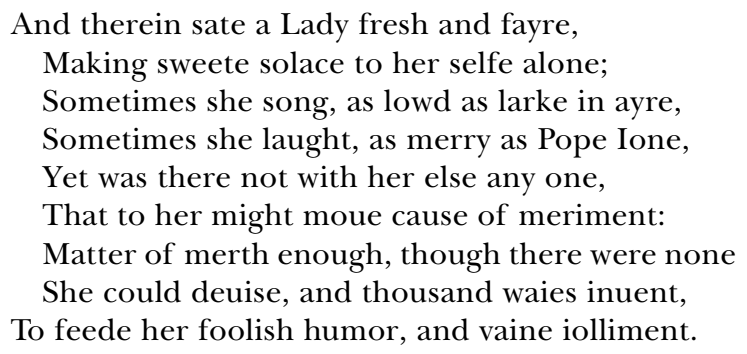

Despite the dismissive moralizing tag in the closing alexandrine, the stanza, like Guyon, remains fascinated with the spectacle of a creative, self-moving feminine presence whose pleasure provides a source of mobility for others. Phaedria and her boat constitute the main form of public transport in the waters that surround Acrasia's Bower of Bliss, providing passage for Cymochles and Guyon, who, stranded at the edge of the Idle Lake, are at once in need of and distracted by her services. Cymochles, having been spurred into violence by the shaming rebukes of Atin (who calls him "a womanish weake knight" [2.5.36]), is once again pacified by the influence of Phaedria, for

Her light behauiour, and loose dalliaunce

Gaue wondrous great contentment to the knight,

That of his way he had no souenaunce,

Nor care of vow'd reuenge and cruell fight.

Although Phaedria may be described as a "weak wench" who has caused Cymochles to "yield his martial might," she also has the power to quench "his flamed minde." Indeed, "sensuall delight," despite its shady reputation, seems to have a beneficial effect, proving that "easie is, t'appease the stormie winde / Of malice in the calme of pleasaunt womankind" (2.6.8). Pyrochles suffers notably from being inflamed by Furor, or fury, as does Guyon on a few occasions; while Guyon fails in his attempt to dominate with sheer force Furor and Occasion, Phaedria cools the "malice" incited in Cymochles by the troubling Atin. She lulls Cymochles to sleep with a song borrowed from Tasso's Gerusalemme liberata, in which the valiant Rinaldo remains captive to the enchantress Armida, whose singing sends him into a deep slumber that prevents him from completing his heroic quest. If, for Tasso, Armida's song prevents masculine assertion, Spenser redeploys the 
song to suggest that the pleasures of the body at rest are an antidote to violent action. Similarly, when Cymochles and Guyon meet on Phaedria's island, a vicious fight breaks out, which Phaedria, again, pacifies. Throwing herself at their feet, she reproves their cruelty and appeals to any kind of love or pity that could "find place" or "empierce" their "iron breasts." Phaedria woos the men away from the vicious, mechanical masculinity they enact by invoking, too, the wooing of Mars by Cupid and Venus:

Mars is Cupidoes frend,

And is for Venus loues renowmed more

Than all his wars and spoiles, the which he did of yore.

Therewith she sweetly smyld.

Phaedria envisions a world of demilitarized love. While such an ethos appears in association with seemingly reprehensible experiences of lewd pleasure, she once again receives narrative approbation for her success: "Such powre haue pleasing wordes: such is the might / Of courteous clemency in gentle hart" (2.6.36).

Phaedria embodies energy unconstrained by notions of virtuous force. Quests govern the actions of Redcrosse and Guyon, setting the knights tasks demanding that their energy be converted to masculine force that is expropriated as labor. Furthermore, a whole metaphysics of desire attends the quests assigned by the abscent Gloriana, who serves as the elusive and ultimate object of desire for Arthur, suggesting that Magnificence, the encompassing virtue of The Faerie Queene, is complete only when the knight obtains his lady. Unlike Guyon, or even the more susceptible Redcrosse Knight, Phaedria does not employ the violence of masculine quest that propels so many knights so disastrously through the landscape of The Faerie Queene. She has no particular quest, and even her distraction of various knights seems to adhere to little pattern; she is not a Duessa or an Archimago, attempting to systematically defeat the virtuous knights. Yet to the extent that figures of feminine agency, self-sufficiency, and pleasure, such as Phaedria, the fountain nymphs, and Acrasia, threaten the masculine power that provides the engine of epic action, they are opposed by Guyon's violence and the Palmer's rectitude.

Indeed, although in Tasso's Gerusalemme liberata the knights who save Rinaldo are ferried to her secret island by a powerful woman who stands in for the near magical might of reason, Guyon and the Palmer employ a boatman of great masculine force who "strongly he them rowes" through the perilous waters that he strikes, drives, and strives 
against (2.12.5). Whereas Phaedria glides easily through the water, masculine locomotion can be brutal:

So forth they rowed, and that Ferryman
With his stiffe oares did brush the sea so strong,
That the hoare waters from his frigot ran,
And the light bubles daunced all along,
Whiles the salt brine out of the billowes sprong.

Masculine energy is not only vehement but, interestingly, again the object of appropriation. Although they all are in motion ("they rowed"), the only one expending energy at this point is the laboring ferryman. The Palmer quells waves and drives away sea creatures, figures of elemental energy, while Guyon saves his violence for the bower itself. Once again, energy is expropriated and alienated from the laboring body; this expropriation we may call masculinity. Feminine energy, however, evades capture, developing alternate circuits of operation. More than just targets of moral condemnation, Phaedria's tactics (fascination, diversion, distraction, and delay-all characteristic of the genre of romance) enable action. They resist progress when such progress relies on the violence of estranged labor.

Even the spectacle of Acrasia hovering over the body of the sleeping Verdant suggests both boyish and feminine erotic energies. Acrasia elicits (rather than contains or constrains) that energy. The Palmer and Guyon, however, attempt to appropriate and economize the energies of poetry and sexuality, as figured in their capture of Acrasia:

suddein forth they on them [Acrasia and Verdant] rusht, and threw A subtile net, which onely for that same

The skilfull Palmer formally did frame.

Guyon and the Palmer, as they reenact the guileful jealousy of Vulcan, reorient once more the governing forces of eros and heros. Venus and Cupid disarm Mars in the proem to the 1590 edition of The Faerie Queene and again on Phaedria's island, and here Verdant plays both Mars and Cupid to Acrasia's Venus. The triad is, however, reconstituted by the reference to Vulcan, a god lamed and emasculated by his father's violence and later cuckolded by his wife. We might think of Vulcan as the laboring god, a figure working in his forge to create objects and devices for others, objects he does not himself enjoy or use. Vulcan is the figure, par excellence, of alienation: from pleasure, from his body, and from the products of his labor. 
Although Guyon and the Palmer share the last word in the Bower of Bliss, sharing too the sententious final stanza, the object of their closing condemnation, Gryll, provides a striking reminder of the energy of pleasure. Most of Acrasia's victims are restored to human form, but one, formerly a hog, "Repyned greatly, and did him miscall / That had from hoggish forme him brought to naturall" (2.12.86). While some of Acrasia's victims experience only hatred for the captured Acrasia, Gryll, like Verdant, experiences regret. Verdant, although lectured at by Guyon and the Palmer, is taken away, "both sorrowful and sad," as if restoration were the source of his unhappiness. Gryll, according to Guyon, represents the lowest of the low, displaying "the mind of beastly man / That hath so soone forgot the excellence / Of his creation" (2.12.87). The Palmer remarks:

The donghill kinde

Delightes in filth and fowle incontinence:

Let Gryll be Gryll, and haue his hoggish minde;

But let vs hence depart, whilest wether serues and winde.

While Verdant sighs at the necessity of once again punching his virtuous time card, Gryll refuses to participate in the experience of labor governed by Guyon and the Palmer, an experience in which "man alienates himself," and engages in "a labor of self-sacrifice, of mortification." Gryll resists not from mere moral depravity but, we might say, as a consequence of his status as a worker of masculinity. In a system in which one's energy is demanded, Marx argues, "man (the worker) only feels himself freely active in his animal functions-eating, drinking, procreating ... and in his human functions he no longer feels himself to be anything but an animal. What is animal becomes human and what is human becomes animal." 71

While Gryll maintains a hoggish mind, the Palmer and Guyon exit abruptly, without the elaborate ending of the Legend of Holiness, in which a whole stanza announced the need for narrative progress by enlisting the readers as "iolly Mariners" (1.12.42) who help prepare the ship of the poem for its next voyage. Here, the Palmer and Guyon possess a worklike attitude, subject as they are to weather and wind for their own locomotion. And indeed, this reference to the utility of wind and weather is rare, if not unique, thus far in The Faerie Queene. Elsewhere, weather contributes either to allegorical significance and the progress of plot, as when Redcrosse and Una seek shelter from the 
storm in the wood of error, or to metaphorical valence, as when the poem in its progress is described as a ship at the close of the Legend of Holiness. At the close of the Legend of Temperance, Guyon and the Palmer risk being stranded by the vital, natural forces they seek to contain.

The pleasurable liquidity, figured in this text in disarmed masculine bodies and in mobile feminine bodies, satisfies Fredric Jameson's understanding of the "proper political use of pleasure." Jameson argues, "So finally the right to a specific pleasure, to a specific enjoyment of the potentialities of the material body-if it is not to remain only that, if it is to become genuinely political, if it is to evade the complacencies of 'hedonism'-must always in one way or another also be able to stand as a figure for the transformation of social relations as a whole." ${ }^{72}$ In the landscape of The Faerie Queene, the real quest is to defeat varieties of alienation that render pleasure (or pain) a form of stupefaction that disables the body's vulnerability to the experiential and ethical dimensions available in a common corporeality.

It seems an unacknowledged irony that literary critics have been inclined to side with Guyon, the Palmer, and the long histories of poetics that violently reject the pleasures of poetry or anxiously subject them to the work of virtue while also locating in such acts of moralistic destruction evidence of the ethically compromised nature of literary texts and their authors. Neither readerly dismay at the destruction of the Bower of Bliss nor a simple taste for its luscious excesses is sufficient to explain the complex work of pleasure in the Legend of Temperance. For Spenser, the pleasure of poetry rests neither in beauty nor delight per se. As long as we imagine pleasure as an inducement to or perversion of virtue, we fail to understand the way pleasure disarms the heroic masculine body whose flesh is otherwise subject to a regime of virtuous labor. Through these acts of disarmament, the Legend of Temperance activates the sensuous vulnerability of laboring bodies alienated from the capacity to experience their own bodies (and the bodies of others) and, in such experience, to enter into a commonality that Spenser imagined as harmony or concord.

Cascades of significant rhyme ("boy," "toy," "joy," "coy"), spectacles of the pleasured and disarmed male body, figures of the female body in states of self-pleasure and autonomous motion, and the highly sensuous landscape of the Bower of Bliss itself all serve as signatures of Spenser's project, in the Legend of Temperance, to understand the radical consequences of aesthetic pleasure. This project is one to which scholars of early modern poetics and historians of sexuality

72. Jameson, "Pleasure," 13-14. 
might profitably turn with The Faerie Queene as a vital archive. For Spenser, the pleasures depicted in poetry or enjoyed as poetry constitute a form of resistance to an ethos of aggressive moralistic heroism and activate the sensuous capacities of the body. Pleasure, not unlike pain, creates a sense of vulnerability from which arise ethical dispositions rooted in common corporeality. That infamously elusive and potentially heretical comparison of the Bower of Bliss with "Eden selfe, if ought with Eden mote compare" comes into focus as we understand the bower to be, ultimately, "sweete and holesome" (2.12.52). The Bower of Bliss may not seem "sweete and holesome" to workers of virtue such as Guyon and the Palmer, but as pleasure integrates the feeling body into a sensuous landscape in which ethical action with respect to other feeling bodies is possible, the bower may indeed compare favorably with "Eden selfe." 